Ankara Üniversitesi Eğitim Bilimleri Fakültesi Dergisi

Yıl: 2019, Cilt: 52, Sayı: 3, 869-890

DOI: 10.30964/auebfd.461440, E-ISSN: 2458-8342, P-ISSN: 1301-3718

\title{
Öğretmenlik İmajı: Bir Ölçek Geliştirme Çalışması
}

\begin{tabular}{lccc}
\hline MAKALE TÜRÜ & Başvuru Tarihi & Kabul Tarihi & Yayın Tarihi \\
Araştırma Makalesi & 19.09 .2018 & 08.08 .2019 & 04.10 .2019 \\
\hline
\end{tabular}

\author{
Mustafa Özgenel \\ İstanbul Sabahattin Zaim Üniversitesi \\ Metin Işsk \\ Milli Eğitim Bakanlığı \\ İsa Bahat \\ Kırşehir Ahi Evran Üniversitesi
}

\begin{abstract}
Öz
$\mathrm{Bu}$ araştırmanın amacı, eğitim sisteminin en önemli aktörlerinden biri olan öğretmenlerin mesleki imajlarının toplum (veliler) tarafından nasıl algılandığını belirlemeye yönelik Likert türü bir ölçek geliştirmektir. Araştırmaya üç faklı çalışma grubu dâhil edilmiştir. Araştırmada sırasıyla açımlayıcı faktör analizi (AFA) 546 katılımcı, doğrulayıcı faktör analizi (DFA) 304 katılımcı ile yapılmıştır. Test-tekrar test uygulaması için 93 veli katılmıştır. 50 maddelik taslak ölçeğin yapı geçerliğinin test edilmesi için uygulanan faktör analizi sonucunda dört boyuttan ve 19 maddeden oluşan bir ölçme aracı elde edilmiştir. Birinci faktör Kişisel Özellikler, ikinci faktör Mesleki Özellikler, üçüncü faktör Toplamsal Statü ve dördüncü faktör Mesleki Tercih olarak adlandırılmıştır. AFA ile elde edilen dört faktörlü yapı, DFA ile test edilmiştir. Uyum indekslerine göre önerilen dört faktörlü yapı doğrulanmıștır. Ölçeğin genel Cronbach Alpha güvenirlik katsayısı 0.86 olarak hesaplanmıştır. Ayrıca ölçeğin güvenirliği için bağımsız gruplar t-testi sonucunda, alt-üst \% 27'lik gruplar arasında madde ve faktörlerin ayırt edici olduğu; madde toplam ve madde kalan korelasyon değerlerinin anlamlı olduğu saptanmıştır. Faktörler arasındaki korelasyon katsayıları ve test-tekrar test çalışması sonucunda korelasyon katsayısı, ölçeğin tümü için anlamlı bulunmuştur. Gerçekleştirilen analizlere göre ölçeğin geçerliği ve güvenirliği sağlanmıştır. Ölçeğe Öğretmenlik Mesleği İmaj Ölçeği (ÖMİÖ) ismi verilmiştir.
\end{abstract}

Anahtar sözcükler: İmaj, öğretmenlik mesleği, mesleki imaj.

\footnotetext{
${ }^{1}$ Sorumlu Yazar: Dr. Öğr. Üyesi, Eğitim Fakültesi, Temel Eğitim Bölümü, E-posta: mustafa.ozgenel@izu.edu.tr, https://orcid.org/0000-0002-7276-4865

${ }^{2}$ Müdür, Koç Ortaokulu, E-posta: metinziya09@ hotmail.com, https://orcid.org/0000-0002-0890-6267

${ }^{3}$ Öğr. Gör., Kaman Uygulamalı Bilimler Yüksekokulu, Yönetim Bilişim Sistemleri Bölümü, Yönetim Bilişim Sistemleri Anabilim Dal, E-posta: isabahat@ahievran.edu.tr, https://orcid.org/0000-0002-56002449
} 
Eğitim, bireyleri bilişsel, duyuşsal ve devinişsel alanlarda yaşama hazırlayan, toplumların ve ulusların sosyo-kültürel, ekonomik ve teknolojik gibi birçok alanda kalkınmasını ve gelişmesini destekleyen çok önemli ve bir o kadar da karmaşık bir etkendir. Öğretmenler ise dünyanın asil mesleklerinden biri olarak eğitim hizmetini sunan (Ansari ve Malik, 2013), sunulan eğitimin niteliğini belirleyen (Secretariat of the Pestalozzi Programme, 2014) ve genel olarak eğitim sisteminin vazgeçilmez aktörleridir (Çelikten, Şanal ve Yeni, 2005; Gönülaçar, 2016; Kıroğlu ve Elma, 2009). Örneğin, Güney Kore ve Finlandiya'da eğitim, sosyal kalkınmanın önemli bir bileşeni olarak görülmekte ve öğretmenlere yüksek saygı gösterilmektedir (Kim, 2007; Lee, 2010; Malaty, 2006). Bu iki etmen Güney Kore'nin ve Finlandiya'nın PISA sınavlarındaki başarılarına önemli katkılar sağlamış ve bu ülkelerin eğitim sitemleri diğer ülkelerin dikkatini çekmiştir.

Karaman'a (2008) göre bir eğitim sisteminin niteliği ancak sistem içindeki öğretmenlerin niteliği kadar iyidir. Öğretmenlerin eğitime olan katkıları yeterince bilinmemektedir (Secretariat of the Pestalozzi Programme, 2014). Bu nedenle günümüzde ve gelecekte öğretmen ve öğretmenlik mesleğinin toplum tarafindan nasıl algılandığ 1 ve toplumun tümüne eğitim hizmeti sunan öğretmenlerin mesleki imajı daha çok önem kazanmaktadır (Bağçeci, Çetin ve Ünsal, 2013; TEDMEM, 2014). Başka bir ifade ile öğretmenlerin toplum üzerinde bıraktıkları izlenimler yani toplumun öğretmenliğe yönelik algıları, onların mesleki imajını belirlemektedir (Polat, 2011). Toplumdaki öğretmen imaj1, öğretmenlere duyulan güven ile öğretmenlik mesleğine yönelik gösterilen saygınlığın ifadesidir (Tengelimoğlu ve Öztürk, 2004). İmaj kavramı, "insanın duyuları ile algıladığı ve zihninde oluşan izlenim" șeklinde tanımlanmaktadır (Türk Dil Kurumu-TDK, 2018). Mesleki imaj ise bir mesleğin içerisinde bulunan toplum tarafindan değerlendirilmesi, bu değerlendirmenin genel kabul görmesi (Emiroğlu; 2000) veya insanların bir meslek hakkında sahip olduğu inançların, fikirlerin ve izlenimlerin toplamıdır (Bağçeci ve di ̌̆., 2013; Roberts, 2003).

Bireyin yaşamında eğitim-öğretim sürecinde karşılaştığı öğretmenler yaşamsal bir rol oynamaktadır. Örneğin, öğretmenin vereceği kötü bir karar bireyin eğitimini yarım birakmasına neden olabilmektedir (Hargreaves ve Fullan, 2000). Bu nedenle öğretmenlerin eğitim sistemlerindeki öneminin ve gerekliliğinin hem toplumlar hem bireyler hem de devletler tarafından farkına varılması, nitelikli öğretmen yetiştirmenin sadece yüksek maaş ödeme ile olamayacağının göz önünde bulundurulması ve toplumsal saygının ön plana çıkarılması gerekir. Bir toplumda bir mesleğin imajını belirleyen çok sayıda etken vardır. Bu etkenlere mesleğin toplum tarafından algılanan önemi veya çekiciliği, ücret ve çalışma koşulları, gelenek, güven, sosyal durumu ve toplum tarafindan tercih edilmesi örnek olarak verilebilir (Secretariat of the Pestalozzi Programme, 2014). Bu bağlamda öğretmenlerin mesleki imajlarının geliştirilmesi veya iyileştirilmesi önemli bir adım olarak görülebilir. Öğretmenlerin mesleki imajlarını geliştirmek veya iyileştirmek için okul ile toplum arasında güçlü bir ilişki kurulmalı, okullar toplum tarafindan ziyaret edilmeli, topluma öğretmenlerin çalışmalarını izleme firsatı verilmeli, medyada olumlu iletiler verilmeli, öğretmenlik 
mesleğinin sosyal ve eğitsel önemi vurgulanmalı, öğretmenlik mesleğini tanıtma programları düzenlenmeli, topluma olumlu öğretmen modelleri sunulmalı ve olumsuz mesleki algılar düzeltilmelidir (Education, Audiovisual and Culture Executive Agency-EACEA, 2015).

Çağımızda teknolojinin öğretim araçlarını geliştirmesi ve öğrenme-öğretme sürecini kolaylaştırıcı yeni tekniklerin bulunması hem öğretmenlik mesleğinin önemini artırmıştır (Karaman, 2008) hem de statüsünü değiştirmiştir (Hargreaves, 2000). Bu yüzden günümüzde öğretmenlerin mesleki gelişimine yönelik yeni araştırmaların yapılmasına ve mevcut mesleki imajının tanımlanmasına gereksinim duyulmakta ve öğretmenlerle ilgili daha çok araştırma yapılması önerilmektedir (Devrim, 2010; Tok, 1997). Öğretmenlerin ve mesleki imajlarının toplumun okul temsilcisi olan veliler tarafından nasıl algılandığı ve mesleğe yönelik düşünceleri öğretmenlerin performansını etkileyen en önemli etkenden biri olarak kabul edilebilir. Çünkü öğretmenler, mesleki imajlarına uygun davranışlarda bulunurlar (Akyüz, 1978; Ünsal ve Bağçeci, 2016).

Öğretmenler, mesleklerinin saygın ve değerli olduğunu düşünmesine karşın (Hargreaves ve diğ., 2007), değişen toplumsal yap1 doğrultusunda öğretmenlik mesleğine yüklenen rol ve sorumluluklar değişmektedir. Bu değişim, toplumun ve velilerin öğretmene verdiği değer ve önemin değişmesine de neden olmaktadır. Bu konuda Uluslararası Öğrenme ve Öğretme Anketi (Organisation for Economic Cooperation and Development-OECD, 2014) yapılmıştır. Anket sonuçlarına göre Fransa'da öğretmenlerin çoğunluğu mesleklerini olumlu algılarken, İtalya'da öğretmenlerin çoğunluğu toplumun öğretmenlik mesleğine değer vermediğini düşünmektedir. İspanya ve Polonya'da öğretmenlik mesleği toplumun en saygın meslek grupları arasındadır. Letonya, İsveç ve Belçika'da öğretmenlik mesleğine yönelik toplumsal algının düşük olduğu belirlenmiştir.

Türkiye'de yapılan araştırmalarda ise öğretmen adaylarının çoğunluğu öğretmenlik mesleğinin toplum tarafından saygın bir meslek olarak algılanmadığını (Karamustafaoğlu ve Özmen, 2004) ve öğretmenlerin çoğunluğu toplumsal statülerinin düştüğünü ifade etmişlerdir (Özpolat, 2002). Ayrıca öğretmenlerin niteliği (Yetim ve Göktaş, 2004), mesleki özellikler (Çelikten, ve diğ., 2005), öğretmenlerin sorunları (Yaman, Yaman ve Eskicumal1, 2001), okul imajı (Bahçeci, 2009), mesleki statü (Torun, 2010), mesleğe yönelik tutum (Semerci, Semerci, Eliüşük ve Kartal, 2012) ve öğretmenlik mesleği imajını etkileyen çeşitli etkenlere (Ünsal ve Bağçeci, 2016) yönelik çalışmalar da bulunmaktadır. Belirtilen araştırmalar değerlendirildiğinde ülkelerin öğretmenlik mesleği imajlarına yönelik algılarının farklılık gösterdiği söylenebilir. Bu bağlamda toplumun öğretmenlik mesleğinin imajı ile ilgili algılarının belirlenmesi önemli ve değerli görülmektedir. Türkiye'de öğretmenlik mesleğinin saygınlığının artırılması ve imajının olumlu algılanması için öğretmenlerin topluma verdiği eğitim hizmetinin niteliğinin politikacılar, araştırmacılar, öğretmenler ve toplum tarafından doğru bir şekilde değerlendirilmesi ve tam olarak anlaşılması gerekir. Öğretmenlerin ve toplumun öğretmenlik mesleğine 
yönelik imaj algıları, öğretmenlik mesleğinin çekiciliğini artırabilir. Başka bir ifade ile öğretmenlik mesleğinin imajını belirlemenin ve şekillendirmenin ilk ve belki de en önemli yolu, toplumu temsil eden ve eğitim hizmeti alan öğrenci velileri tarafindan nasıl algılandığını ölçebilmektir. Alanyazın incelendiğinde öğretmenlik mesleğinin imajını belirlemek amacıyla öğretmen algılarına göre çalışmalar yapıldığı (Bağçeci ve diğ., 2013), ancak toplumun okul temsilcisi olan velilerin algılarını ölçmeye yönelik yeterli çalışmanın yapılmadığı görülmüştür. Bu noktada, veli algılarına göre öğretmenlik mesleğinin imajını ölçmeyi amaçlayan bir ölçek geliştirmek önemli görülmüş ve bu araştırmada velilerin eğitim sisteminin temelini oluşturan öğretmenlik mesleğine yönelik algılarını belirlemeye yönelik ölçek geliştirmek amaçlanmıştır. Geliştirilen ölçeğin, öğretmenlik mesleğinin imajı ile ilgili yapılacak çalışmalara ve alana katkı sağlayacağı düşünülmektedir.

\section{Yöntem}

Araştırmanın modeli, çalışma grubu, ölçek geliştirme basamakları ve istatistiksel analiz bilgileri yer almaktadır.

\section{Araștırma Modeli}

$\mathrm{Bu}$ araştırmada öğretmenlik mesleği imaj ölçeğinin geliştirilmesi amacıyla betimsel tarama modeli kullanılmıştır. Betimsel tarama modeli, bir gruba ait özelliği var olduğu biçimiyle betimlemeyi amaçlayan modeldir (Karasar, 2007).

\section{Çalışma Grubu}

Ölçek geliştirme aşamalarından faktör analizinde örneklem büyüklüğü için madde sayısının 5 veya 10 katı yeterli olduğu ileri sürülmektedir (Bryman ve Cramer, 2001, akt., Seçer, 2015). Ölçek geliştirme sürecinde örneklem büyüklüğü belirlenirken madde sayısının 10 katı alınmış ve faktör analizi için 546, doğrulayıcı faktör analizi (çalışmanın sonraki bölümlerinde DFA olarak kullanılmıştır.) için 304 ve test-tekrar test uygulaması için 93 öğrenci velisine ulaşılmıştır. Açımlayıcı faktör analizi (çalışmanın sonraki bölümlerinde AFA olarak kullanılmıştır) çalışmasında velilerin \% 61.7'si (337) kadın ve \% 38.3'ü (209) erkektir. Velilerin \% 3.3'ü (18) 20 30 yaş, \% 50.5'i (276) 31-40 yaş, \% 39.6'sı (216) 41-50 yaş ve \% 6.6'sı (36) 51 yaş ve üzerinde; \% 24.2'si (132) ilkokul, \% 19.8'i (108) ortaokul, \% 33.0'1 (180) lise, \% 10.1'i (55) önlisans ve \% 13.0'ı (71) lisans mezuniyetine sahiptir. DFA'ya 163'ü kadın 141 'i erkek toplam 304 ve test-tekrar test uygulamasına 50'si kadın 43'ü erkek toplam 93 veli katılmıştır.

\section{Ölçek Geliștirme Basamakları}

Ölçeğin geçerliğini sağlamak için öğretmenlik mesleği imajı ile ilgili alanyazın taranmış, söz konusu mesleki imaj tanımlanmış, kuramsal çalışmalar ve konuyla ilgili ölçekler incelenmiş, madde havuzu oluşturulmuş, maddeleri değerlendirmek için uzman ve öğretmen görüşlerine başvurulmuş, betimsel analiz, AFA, ölçek toplam puanı ile faktörler arası korelasyon analizi ve DFA yapılmıştır. Öğretmenlik Mesleği İmajı Ölçeğinin geliştirilmesi sürecinde öncelikle ögretmenlik mesleği imajı 
öğretmenin sahip olması gereken nitelikleri velilerin nasıl tanımladığ belirlenmiştir. Öğretmenlik meslek imajını tanımlamak ve belirlemek için alanyazında yer alan öğretmenlik mesleği özellikleri, öğretmen yeterlikleri ve konu ile ilgili araştırmalar incelenmiştir.

Kuramsal bilgiler ve ilgili ölçekler incelenerek oluşturulan madde havuzundan 67 maddelik bir taslak ölçek elde edilmiştir. Taslak ölçeği şekil, içerik, anlaşılırlık ve dilbilgisi bakımından değerlendirilmek üzere ölçme-değerlendirme ve eğitim yönetimi alanlarından 7 uzmanın görüşlerine başvurulmuştur. Uzmanların uygun görmedikleri 17 madde ölçekten çıkarılmıştır. Beşli Likert tipinde hazırlanan taslak ölçekte yer alan tüm maddeler olumlu puanlanmaktadır. Ölçek 19 madde ve 4 alt boyuttan oluşmaktadır. Ölçekten en düşük 19, en yüksek 95 puan alınmaktadır. Ölçekten elde edilen toplam puanın yüksekliği, öğretmenlik mesleğinin imaj algısının da yüksek olduğunu göstermektedir.

\section{Verilerin Çözümlenmesi}

Ölçeğin geçerliği ile ilgili istatistiksel kanıtlar sunmak amacıyla AFA ve DFA yapılmıştır. AFA'ya uygunluğu ise sırasıyla Kaiser-Meyer-Olkin (KMO) ve sonrasında Bartlett's testi ile belirlenmiştir. Ölçeğin yapı geçerliğini belirlemek için AFA'da sırasıyla temel bileşenler analizi ve Varimax dik döndürme yöntemleri uygulanmıştır. Ölçek ile maddeler arasındaki ilişkiyi belirlemek amacıyla ölçek toplam puanı ile faktörlerin toplam puanları arasındaki korelasyon katsayıları hesaplanmıştır. DFA ile AFA'dan elde edilen yapı test edilirken ki-kare değeri ve uyum indeksleri incelenmiştir. DFA'da modelin geçerli olması için uyum indekslerinin kabul edilebilir düzeyde olması gerekmektedir.

Geliştirilen ölçeğin güvenirliğini test etmek için Croanbach Alfa değeri hesaplanmıştır. Ölçeğin bütünü ile maddeleri arasındaki ilişkiye kanıt sunmak amacıyla gerekli korelasyon katsayıları hesaplanmıştır. Maddelerin ayırt ediciliğini belirlemek için bağımlı gruplar t- testi analizleri yapılmıştır. Verilerin analizi istatistik paket programları (SPSS ve AMOS) ile yapılmıştır.

\section{Bulgular}

$\mathrm{Bu}$ çalışmada öğretmenlerin meslek imajları konusunda toplum (veli) algısını ölçmeyi hedefleyen geçerliği ve güvenirliği yapılmış Öğretmenlik Mesleği İmaj Ölçeği geliştirilmiştir.

\section{Geçerlik Çalışmalarına İlişkin Bulgular}

Ölçek aracılığıyla toplanan verilerin analiz edilmesi için puanların toplanabilir ve normal dağılım göstermesi gerekir (Özdamar, 2016). Bu amaçla taslak ölçekten elde edilen verilere ilişkin betimsel değerler Tablo 1'de verilmiştir. 
Tablo 1

Öğretmenlik Mesleği İmaj Ölçeğinin Betimsel İstatistik Değerleri

\begin{tabular}{lr}
\hline Frekans & Değerler \\
Aritmetik Ortalama & 546 \\
Standart Sapma & 3.93 \\
En Küçük Puan & .017 \\
En Yüksek Puan & 1.92 \\
Ranj & 5.00 \\
Çarpıklık & 3.08 \\
Basılık & -.170 \\
Ortanca & .866 \\
Kolmogrov Smirnov & 3.91 \\
$p$ & .033 \\
\hline
\end{tabular}

Veri setinin normal dağılım gösterip göstermediğine karar vermek için Kolmogorov-Smirnov anlamlılık değeri (p) veya basıklık ve çarpıklık katsayıları incelenir. Verinin normal dağılması için Kolmogorov-Smirnov değerinin .05'ten büyük çıkması $(\mathrm{p}>.05)$ veya basıklık ve çarpıklık değerlerinin -1 ile +1 değerleri arasında olması önerilir (Çokluk, Şekercioğlu ve Büyüköztürk, 2012). Tablo 1'de görüldüğü üzere Kolmogorov-Smirnov $(\mathrm{p}=.200)$ değeri anlamlı farkl1lık göstermemektedir. Ayrıca basıklık değeri 0.866 ve çarpıklık değeri -.170'tir. Kolmogorov-Smirnov değeri anlamlı farklılık göstermediğinden $(p>.05)$; basıklık ve çarpıklık katsayıları \pm 1 aralığı içinde kaldığından verilerin normal dağılım gösterdiğine karar verilmiş ve faktör analizi aşamasına geçilmiştir. Faktörlerin aldıkları özdeğer ve açıkladıkları varyans miktarları temel bileşenler analizi ile belirlenmiştir. Tablo 2'de analizden elde edilen faktörlere ait özdeğerler ve açıkladıkları varyans miktarları (çalışmanın sonraki bölümlerinde AVM olarak kullanılmıştır) gösterilmiştir.

Tablo 2

Illk Analizden Elde Edilen Özdeğerler ve AVM

\begin{tabular}{lrrr}
\hline Faktör & Özdeğer & Varyans & Yığmalı Toplam \\
\hline 1 & 12.797 & 25.594 & 25.594 \\
2 & 4.436 & 8.871 & 34.466 \\
3 & 3.180 & 6.361 & 40.826 \\
4 & 2.022 & 4.045 & 44.871 \\
5 & 1.498 & 2.996 & 47.867 \\
6 & 1.466 & 2.933 & 50.800 \\
7 & 1.283 & 2.566 & 53.365 \\
8 & 1.163 & 2.325 & 55.691 \\
9 & 1.085 & 2.170 & 57.861 \\
10 & 1.041 & 2.082 & 59.943 \\
\hline
\end{tabular}


Tablo 2'de görüldüğü üzere taslak ölçeğin özdeğeri 1'den büyük 10 faktörden oluştuğu görülmektedir. 10 faktör, toplam varyansın \% 59.943'ünü açıklamaktadır. Birinci faktörün özdeğeri \% 12.797 ve açıkladığı varyans miktarı \% 25.594'tür.

Ölçeğe son biçimini vermek için yapılan AFA'da madde yükü .32'nin altında olan maddeler çıkarılırken ilk önce en düşük madde yükü olan madde çıkarılmış, her defasında analiz yenilenerek diğer maddelerdeki yükler tekrar kontrol edilmiştir. Bu işlem yapılırken aynı zamanda madde yükleri arasındaki fark .1'den düşük olduğunda en düşük olandan başlanarak çıkarılmış ve analiz yenilenmiştir. Yapılan analizler sonucunda 31 madde taslak ölçekten çıkarılmıştır.

Taslak ölçeğin kaç faktörden oluştuğunu belirlemek için AVM incelenmiş ve 19 maddenin 4 faktöre dağldiğ $\breve{g}_{1}$ belirlenmiştir. Tablo 3'te faktör yükleri ve AVM verilmiştir.

Tablo 3

Son Analizden Elde Edilen Özdeğerler ve AVM

\begin{tabular}{lrrr}
\hline Faktör & Özdeğer & Varyans & Yı̆̆malı Toplam \\
\hline 1 & 6.560 & 34.527 & 34.527 \\
2 & 2.399 & 12.626 & 47.152 \\
3 & 2.083 & 10.965 & 58.118 \\
4 & 1.186 & 6.245 & 64.362 \\
\hline
\end{tabular}

Tablo 3 incelendiğinde toplam varyansın \% 64.362'sinin dört faktör ile açıklandığı görülmektedir. Birinci faktör varyansın \% 34.527'sini, ikinci faktör \% 12.626'sını, üçüncü faktör \% 10.965'ini, dördüncü faktör \% 6.245'ini açıklamaktadır.

Varimax dik döndürme yöntemi ile maddelerin faktörlere dağılımları belirlenmiş ve yapılan analiz sonucunda ulaşılan madde yükleri Tablo 4'te verilmiştir. Birinci faktör Kişilik Özellikler, ikinci faktör Mesleki Özellikler, üçüncü faktör Toplumsal Statü, dördüncü faktör Mesleki Tercih olarak adlandırılmıştır. Ölçek ise Öğretmenlik Mesleği İmaj Ölçeği olarak isimlendirilmiştir.

Tablo 4

Öğretmenlik Mesleği Imaj Ölçĕ̆inin Faktör ve Madde Yükleri

\begin{tabular}{llllcl}
\hline Madde & Öğretmenlik Mesleği İmaj Ölçeği & (devam ediyor)
\end{tabular}


Tablo 4 (devam)

\begin{tabular}{|c|c|c|c|c|c|}
\hline Madde & Öğretmenlik Mesleği İmaj Ölçeği & 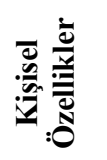 & 离 & 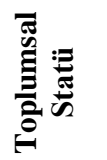 & 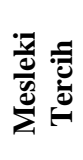 \\
\hline s26 & $\begin{array}{l}\text { Öğretmenler anlayışlı ve hoşgörülü } \\
\text { kişilerdir. }\end{array}$ & .854 & & & \\
\hline s27 & Öğretmenler, güler yüzlü kişilerdir. & .825 & & & \\
\hline s28 & Öğretmenler, örnek alınan kișilerdir. & .689 & & & \\
\hline s30 & Öğretmenler, eleştiri ve öneriye açıktır. & .707 & & & \\
\hline s32 & Öğretmenler, adaletli kişilerdir. & .732 & & & \\
\hline s34 & Öğretmenler, güvenilir kişilerdir. & .745 & & & \\
\hline s7 & $\begin{array}{l}\text { Öğretmenlik, sorumluluk gerektiren bir } \\
\text { meslektir. }\end{array}$ & & .758 & & \\
\hline s8 & Öğretmenlik, özveri gerektiren bir meslektir. & & .825 & & \\
\hline s9 & Öğretmenlik, sabır gerektiren bir meslektir. & & .809 & & \\
\hline s10 & $\begin{array}{l}\text { Öğretmenlik, fedakârlık gerektiren bir } \\
\text { meslektir. }\end{array}$ & & .745 & & \\
\hline s14 & $\begin{array}{l}\text { Öğretmenler, toplum tarafindan } \\
\text { önemsenmektedir. }\end{array}$ & & & .746 & \\
\hline s15 & $\begin{array}{l}\text { Öğretmenler, toplum tarafindan } \\
\text { sevilmektedir. }\end{array}$ & & & .727 & \\
\hline s45 & $\begin{array}{l}\text { Öğretmenlik, toplumda prestijli bir } \\
\text { meslektir. }\end{array}$ & & & .707 & \\
\hline s49 & $\begin{array}{l}\text { Öğretmenlerin, toplumda olumlu bir imajı } \\
\text { bulunmaktadır. }\end{array}$ & & & .639 & \\
\hline s44 & $\begin{array}{l}\text { Öğretmenlik, güvencesi olan bir meslek } \\
\text { olduğu için tercih edilmektedir. }\end{array}$ & & & & .727 \\
\hline s46 & $\begin{array}{l}\text { Öğretmenlik, rahat bir meslek olduğu için } \\
\text { tercih edilmektedir. }\end{array}$ & & & & .844 \\
\hline s47 & $\begin{array}{l}\text { Öğretmenlik, toplumda saygın bir meslek } \\
\text { olduğu için tercih edilmektedir. }\end{array}$ & & & & .707 \\
\hline Toplam & 64.362 & 34.527 & 12.626 & 10.965 & 6.245 \\
\hline
\end{tabular}

Tablo 4 incelendiğinde, yapılan analizler sonucunda ölçekte 19 madde kaldığ görülmektedir. Faktörlerin madde yükü değerleri incelendiğinde birinci faktörün madde yükü değerlerinin .74 ile .79, ikinci faktörün yükü değerlerinin .74 ile .75 , üçüncü faktörün yükü değerlerinin .63 ile .74, dördüncü faktörün yükü değerlerinin .70 ile .84 arasında değiştiği belirlenmiştir.

Öğretmenlik Mesleği İmaj Ölçeği'nin yapı geçerliğine ilişkin madde toplam (çalışmanın sonraki bölümlerinde MT olarak kullanılmıştır) MT puan korelasyon değerleri hesaplanmıştır. Tablo 5'te Öğretmenlik Mesleği İmaj Ölçeği faktörler arası ve toplam puan ile faktörler arası korelasyon katsayıları gösterilmiştir. 
Tablo 5

Öğretmenlik Mesleği İmaj Ölçeği Toplam Puanı ile Faktörler Arasındaki Korelasyonlar

\begin{tabular}{llllll}
\hline & & $\begin{array}{l}\text { Kişisel } \\
\text { Özellikler }\end{array}$ & $\begin{array}{l}\text { Mesleki } \\
\text { Özellikler }\end{array}$ & $\begin{array}{l}\text { Toplumsal } \\
\text { Statü }\end{array}$ & $\begin{array}{l}\text { Mesleki } \\
\text { Tercih }\end{array}$ \\
\hline $\begin{array}{l}\text { Kişisel } \\
\text { Ozzellikler }\end{array}$ & $\mathrm{r}$ & 1 & & & \\
\hline $\begin{array}{l}\text { Mesleki } \\
\text { Özellikler }\end{array}$ & $\mathrm{r}$ & $236^{*}$ & 1 & & \\
\hline $\begin{array}{l}\text { Toplumsal } \\
\text { Statü }\end{array}$ & $\mathrm{r}$ & $.514^{*}$ & $.319^{*}$ & 1 & \\
\hline Mesleki Tercih & $\mathrm{r}$ & $.129^{*}$ & .045 & $.326^{*}$ & 1 \\
\hline Toplam puan & $\mathrm{r}$ & $.870^{*}$ & $.449^{*}$ & $.765^{*}$ & $.447^{*}$ \\
\hline *n $=546$ ve $<<01$ & & & & &
\end{tabular}

$* \mathrm{n}=546$ ve $\mathrm{p}<.01$

Tablo 5 incelendiğinde, toplam puan ile alt boyutlar arasındaki korelasyon katsayılarının pozitif ve anlamlı olduğu görülmektedir $(\mathrm{p}<.01)$. Toplam puan ile Kişisel Özellikler alt boyutunun .87, Mesleki Özellikler alt boyutunun .44, Toplumsal Statü alt boyutunun .76 ve Mesleki Tercih alt boyutunun .44 ilişkili olduğu belirlenmiştir. 4 faktörlü ve 19 maddeden oluşan ölçeğin faktör yapısını doğrulamak amacıyla modele ilişkin yapılan DFA sonuçları Şekil 1'de verilmiştir.

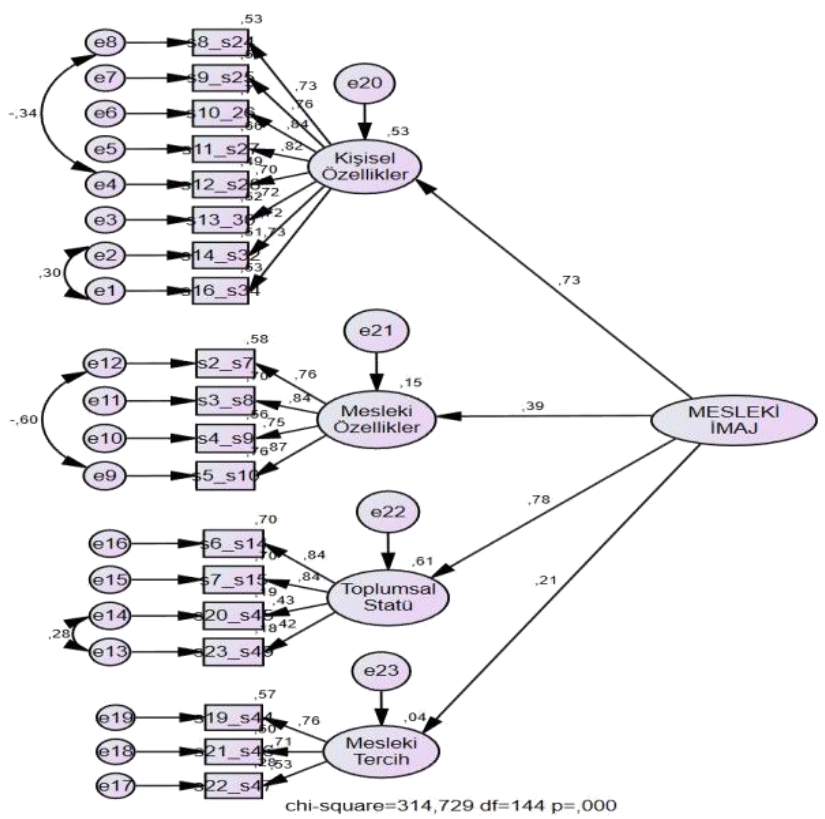

Şekil 1. Doğrulayıcı faktör analizi 
Şekil 1 incelendiğinde ölçeğin madde yükü değerleri, ki-kare değeri, serbestlik derecesi ve p değeri görülmektedir. AFA'dan elde edilen faktör yapısının doğruluğuna karar verebilmek için ki-kare değeri ile bu değerin serbestlik derecesine oranı ve model uyum indeksleri ele alınmıştır. Ki-Kare değerinin serbestlik derecesine oranı $\left(\chi^{2} / \mathrm{df}=314.729 / 144=2.186\right)$, GFI (.905), AGFI (.874), CFI (.938), RMR (.054), SRMR (.062) ve RMSEA (.063) uyum indekslerinin kabul edilir düzeyde (Barret, 2007; Byrne, Shavelson ve Muthen, 1989; Jöreskog, 2004; Kline, 2011; MaydeuOlivares ve Garcia-Forero, 2010; Tabachnick ve Fidell, 2007) olduğu saptanmıştır.

\section{Güvenirlik Çalışmalarına İliş̧kin Bulgular}

Öğretmenlik Mesleği İmaj Ölçeği'nin güvenirliğini kanıtlamak için Cronbach Alfa (çalışmanın sonraki bölümlerinde CA olarak kullanılmıştır) iç tutarlık katsayısı, MT ve madde-kalan (çalışmanın sonraki bölümlerinde MK olarak kullanılmıştır) korelasyon değerleri hesaplanmış, alt-üst \% 27'lik grupların karşılaştırılması ve testtekrar test çalışmaları yapılmıştır. Ölçeğin toplam puan ve faktörlerine ait CA güvenirlik katsayısı Tablo 6'da verilmiştir.

Tablo 6

Öğretmenlik Mesleği İmaj Ölçeğinin CA Güvenirlik Katsayıları

\begin{tabular}{lr}
\hline İmaj Ölçeği & CA İç Tutarlık Katsayıları \\
\hline Kişisel Özellikler & .918 \\
Mesleki Özellikler & .800 \\
Toplumsal Statü & .771 \\
Mesleki Tercih & .686 \\
Toplam Puan & .869 \\
\hline
\end{tabular}

Tablo 6'da ölçeğin alt boyutlarına ait güvenirlik katsayıları verilmiştir. Buna göre Kişisel Özellikler alt boyutu .91, Mesleki Özellikler alt boyutu .80, Toplumsal Statü alt boyutu .77, Mesleki Tercih alt boyutu .68 ve genel güvenirlik katsayısı .86'dir.

Ölçeğin faktörlerinin ayırt edicilik gücünü saptamak amacıyla, ölçekte 546 velinin toplam puanları küçükten büyüğe şeklinde sıralanmış ve bağımsız gruplar t testi yapılmıştır. Bu analizdeki amaç, faktörlerin ayırt etme gücünü belirlemektir. İlişkisiz gruplar t testi analizine ait bulgular Tablo 7'de verilmiştir.

Tablo 7

Öğretmenlik Mesleği İmaj Ölçeği \% 27 Üst ve Alt Gruplar Arasında Yapılan Bă̆ımsız Gruplar t-Testi Sonuçlart

\begin{tabular}{llllllll}
\hline Boyut & Grup & N & Ort & ss & t & sd & p \\
\hline Kişisel Özellikler & Alt & 147 & 23.993 & 5.053 & 25.85 & 292 & .000 \\
\cline { 2 - 5 } & Üst & 147 & 36.612 & 3.079 & & & \\
\hline
\end{tabular}


Tablo 7 (devam)

\begin{tabular}{|c|c|c|c|c|c|c|c|}
\hline Boyut & Grup & $\mathbf{N}$ & Ort & SS & $\mathbf{t}$ & sd & p \\
\hline \multirow[t]{2}{*}{ Mesleki Özellikler } & Alt & 147 & 17.469 & 2.159 & \multirow[t]{2}{*}{10.95} & \multirow[t]{2}{*}{292} & \multirow[t]{2}{*}{.000} \\
\hline & Üst & 147 & 19.585 & .905 & & & \\
\hline \multirow[t]{2}{*}{ Toplumsal Statü } & Alt & 147 & 13.884 & 2.397 & \multirow[t]{2}{*}{20.82} & \multirow[t]{2}{*}{292} & \multirow[t]{2}{*}{.000} \\
\hline & Üst & 147 & 18.646 & 1.393 & & & \\
\hline \multirow[t]{2}{*}{ Mesleki Tercih } & Alt & 147 & 8.591 & 2.678 & \multirow[t]{2}{*}{9.01} & \multirow[t]{2}{*}{292} & \multirow[t]{2}{*}{.000} \\
\hline & Üst & 147 & 11.421 & 2.701 & & & \\
\hline \multirow[t]{2}{*}{ Toplam Puan } & Alt & 147 & 63.938 & 5.646 & \multirow[t]{2}{*}{38.72} & \multirow[t]{2}{*}{292} & \multirow[t]{2}{*}{.000} \\
\hline & Üst & 147 & 86.265 & 4.120 & & & \\
\hline
\end{tabular}

Tablo 7 incelendiğinde söz konusu farklılıklar üst \% 27'lik gruplar lehine gerçekleşmiştir $(p<.01)$. Başka bir ifadeyle faktörler $\% 27^{\prime}$ lik alt ve üst gurubu birbirinden ayırt etmektedir.

Öğretmenlik Mesleği İmajı Ölçeğinin bütünü ile maddeleri arasındaki ilişkiyi belirlemek için yapılan MT ve MK korelasyonları Tablo 8'de verilmiştir.

Tablo 8

Öğretmenlik Mesleği Imajı Ölçeği MT ve MK Analizi Sonuçları

\begin{tabular}{llll}
\hline Faktör & Madde & MT & MK \\
\hline & s24 & $.696^{*}$ & $.632^{*}$ \\
& s25 & $.681^{*}$ & $.622^{*}$ \\
& s26 & $.744^{*}$ & $.696^{*}$ \\
Kişisel Özellikler & s27 & $.731^{*}$ & $.677^{*}$ \\
& s28 & $.719^{*}$ & $.668^{*}$ \\
& s30 & $.652^{*}$ & $.576^{*}$ \\
& s32 & $.646^{*}$ & $.577^{*}$ \\
Mesleki Özellikler & s34 & $.715^{*}$ & $.668^{*}$ \\
\hline \multirow{3}{*}{ Toplamsal Statü } & s7 & $.294^{*}$ & $.246^{*}$ \\
& $\mathrm{~s} 8$ & $.348^{*}$ & $.291^{*}$ \\
& $\mathrm{~s} 9$ & $.327^{*}$ & $.277^{*}$ \\
& $\mathrm{~s} 10$ & $.436^{*}$ & $.371^{*}$ \\
\hline \multirow{3}{*}{ Mesleki Tercih } & $\mathrm{s} 14$ & $619^{*}$ & $.558^{*}$ \\
& $\mathrm{~s} 15$ & $.635^{*}$ & $.580^{*}$ \\
& $\mathrm{~s} 45$ & $.549^{*}$ & $.479^{*}$ \\
& $\mathrm{~s} 49$ & $.559^{*}$ & $.491^{*}$ \\
\hline
\end{tabular}

*p $<.01$ 
Tablo 8'de MT korelasyon değerlerinin $r=.20$ ile $r=.74$ ve MK korelasyon değerlerinin ise $r=.16$ ile $r=.69$ arasında değiştiği ve puanlar arasında .01 düzeyinde anlamlı ilişki olduğu görülmektedir.

Ölçeğin tutarlığına kanıt sunmak amaciyla test-tekrar test uygulaması yapılmıştır. Test-tekrar test analizinden elde edilen faktör ve toplam puanlara ait Pearson korelasyon katsayıları Tablo 9'da verilmiştir.

Tablo 9

Öğretmenlik Mesleği İmajı Ölçeğinin Test-Tekrar Test Korelasyon Katsayıları ve Băgımlı Gruplar t- Testi Sonuçları

\begin{tabular}{lllllllll}
\hline Boyut & Grup & $\mathbf{r}$ & $\mathbf{N}$ & Ort & ss & t & sd & p \\
\hline \multirow{2}{*}{ Kişisel Özellikler } & İlk uygulama & $.480^{*}$ & 93 & 31.82 & 6.17 & .235 & 92 & .815 \\
& Son uygulama & & 93 & 31.96 & 4.86 & & & \\
\hline \multirow{2}{*}{ Mesleki Özellikler } & İlk uygulama & $.418^{*}$ & 93 & 18.48 & 1.92 & .251 & 92 & .802 \\
& Son uygulama & & 93 & 18.53 & 1.90 & & & \\
\hline \multirow{2}{*}{ Toplumsal Statü } & İlk uygulama & $.529^{*}$ & 93 & 16.32 & 2.47 & .044 & 92 & .965 \\
& Son uygulama & & 93 & 16.31 & 2.42 & & & \\
\hline \multirow{2}{*}{ Mesleki Tercih } & İlk uygulama & $.565^{*}$ & 93 & 9.77 & 2.41 & .317 & 92 & .752 \\
& Son uygulama & & 93 & 9.84 & 2.49 & & & \\
\hline \multirow{2}{*}{ Toplam Puan } & İlk uygulama & $.556^{*}$ & 93 & 76.40 & 9.09 & .307 & 92 & .760 \\
& Son uygulama & & 93 & 76.66 & 8.03 & & & \\
\hline *p $<.01$ & & & & & & & &
\end{tabular}

Tablo 9 incelendiğinde; $t$ testi sonucunda bağımlı gruplar için anlamlı farklılık bulunmadığı ( $>$ >05); faktörler ve ölçek toplam puanının ilk uygulama ile son uygulama arasındaki korelasyon katsayılarının $r=.41$ ile $r=.56$ arasında değiştiği görülmüştür.

\section{Tartışma, Sonuç ve Öneriler}

Bu araştırmada, velilerin algılarına göre öğretmenlerin mesleki imajlarını geçerli ve güvenilir bir şekilde ölçebilecek Likert tipi bir ölçek geliştirilmesi amaçlanmıştır. Likert türü ölçekler, ölçülmek istenen özellik konusunda bilgi toplamak için geliştirilen ölçme araçlarıdır (Tezbaşaran, 2008). Ölçeğin yapı geçerliğine ilişkin kanıt elde etmek (Çokluk ve diğ., 2012) ve yapısal teorileri test etmek için AFA yapılır (Baykul, 2015). Faktör analizinden önce KMO ve Barlett's test sonuçlarının AFA'ya uygun olduğu belirlenmiştir. AFA sonucunda 19 madde ve 4 faktörlü bir ölçek elde edilmiştir. Ölçekte yer alan maddeler ilgili alanyazın göz önünde bulundurularak değerlendirilmiş ve birinci faktöre Kişisel Özellikler, ikinci faktöre Mesleki Özellikler, üçüncü faktöre Toplumsal Statü, dördüncü faktöre Mesleki Tercih isimleri verilmiştir.

AFA ile belirlenen faktör yapıları, DFA ile test edilir (Byrne, 2012). AFA ile ölçeğin faktör yapısını test etmek için tekrar veri toplanmış ve ikinci düzey DFA 
yapılmıştır. DFA'dan elde edilen uyum indeksleri 4 faktörlü ve 19 maddelik yapıyı doğrulamıştır.

Ölçekte yer alan maddelerin aynı yapıyı açıklamak için bir bütün oluşturup oluşturmadığını değerlendirmek (Özdamar, 2016) ve ölçekte yer alan maddelerin iç tutarlığını belirlemek için CA katsayısı hesaplanır (Tezbaşaran, 2008). Ölçeğin alt boyutlarının ve genel güvenirlik katsayılarının yeterli olduğu, ölçeğin bir bütün oluşturduğu ve yüksek iç tutarllğa sahip olduğu söylenebilir.

Faktörlerin \% 27'lik alt-üst gruplar tarafından ayırt edilip edilmediğini belirlemek ve bu gruplar arasında karşılaştırma yapmak için bağımsız gruplar t testi yapılması önerilmektedir (Altunışık, Coşkun, Bayraktaroğlu ve Yıldırım, 2004). Gerçekleştirilen bağımsız gruplar $t$ testi sonucunda anlamlı farklılık görülmüştür. Anlamlı faklılığın \% 27'lik üst grup lehine olduğu tespit edilmiştir. Ölçekteki faktörlerin, ölçeği puanlayan grupların ölçülmek istenen özellikler bakımından ayırt ettiği belirlemiştir.

Ölçek maddelerinin ölçülmek istenen özellik ile ilişkisini belirlemek için MT ve MK korelasyon değerleri hesaplanır (DeVellis, çev. 2014; Tavşancıl, 2002). Ölçeğin MT ve MK korelasyon katsayıları incelendiğinde pozitif ve anlamlı ilişki olduğu görülmüştür. Ölçeğin maddeleri ile toplam puan arasında anlamlı ilişki olduğu ve maddelerin öğretmenlik mesleği imajı ile ilişkili olduğu kabul edilebilir.

Ölçme aracının tutarlığının bir göstergesi olarak test-tekrar test çalışmasının yapılması önerilmektedir (Tezbaşaran, 2008). Test-tekrar test uygulaması sonucunda toplam puan ile faktörler arasında pozitif yönde ve anlamlı ilişki olduğu, $t$ testi sonucunda bağımlı gruplar için anlamlı bir farklılık bulunmamıştır. Elde edilen bu bulgulara göre geliştirilen ölçme aracının güvenilir olduğu söylenebilir.

Yukarıda verilen sonuçlar, Öğretmenlik Mesleği İmaj Ölçeği’nin geçerli ve güvenilir olduğunun bir kanıtı olarak gösterilebilir. Geçerlik ve güvenirlik analizleri ve çalışmaları sonunda ölçeğe Öğretmenlik Mesleği İmaj Ölçeği ismi verilmiştir. Ölçeğin alt boyut ve madde dağılımlarının son durumu şu şekilde sıralanmıştır:

- Kişisel Özellikler: 1, 2, 3, 4, 5, 6, 7, 8

- Mesleki Özellikler: 9, 10, 11, 12

- Toplumsal Statü: 13, 14, 15, 16

- Mesleki Tercih: 17, 18, 19

Geliştirilen Öğretmenlik Mesleği İmaj Ölçeği Ek 1'de yer almaktadır. Ölçeğin yapılacak çalışmalarda kullanılması hem ölçeğin geçerliğine ve güvenirliğine hem de alana katkı sağlayacaktır. 


\section{Kaynakça}

Akyüz, Y. (1978). Türkiye'de öğretmenin “öğretmen” ve meslek imaj1. Ankara Üniversitesi Eğitim Bilimleri Fakültesi Dergisi, 11(1), 115-121.

Altunışık, R., Coşkun, R., Bayraktaroğlu, S. ve Yıldırım, E. (2004). Sosyal bilimlerde araştırma yöntemleri. Sakarya: Sakarya Kitabevi

Ansari, P. D., and Malik, P. D. (2013). Image of an effective teacher in 21 st century classroom. Journal of Educational and Instructional Studies, 3(4), 61-64.

Bağçeci, B., Çetin, B. ve Ünsal, S. (2013). Öğretmenlerin mesleki imaj ölçeği. Gaziantep University Journal of Social Sciences, 12(1), 34-48.

Bahçeci, M. (2009). Velilerin okul imajına ilişkin görüşlerinin incelenmesi (Yayımlanmamış yüksek lisans tezi). Marmara Üniversitesi Eğitim Bilimleri Enstitüsü, İstanbul.

Barret, P. (2007). Structural equation modelling: Adjudging model fit. Personality and Individual Differences, 42, 815-824.

Baykul, Y. (2015). Eğitim ve psikolojide ölçme: Klasik test teori ve uygulamast. Ankara: ÖSYM.

Byrne, B. M. (2012). Structural equation modeling with Mplus: Basic concepts, applications, and programming. New York, NY: Routledge Taylor and Francis Group.

Byrne, B. M., Shavelson, R. J., and Muthen, B. (1989). Testing for the equivalence of factor covariance and mean structures: The issue of partial measurement in variance. Psychological Bulletin, 105, 456-466.

Çelikten. M., Şanal. M. ve Yeni, Y. (2005). Yeni öğretmenlik mesleği ve özellikleri. Sosyal Bilimler Enstitüsü Dergisi, 19(2), 207-237.

Çokluk, Ö., Şekerçioğlu, G. ve Büyüköztürk, Ş. (2012). Sosyal bilimler için çok değişkenli istatistik SPSS ve Lisrel uygulamaları. Ankara: Pegem A.

DeVellis, R. F. (2014). Ölçek geliştirme: Kuram ve uygulamalar [Scale development - Theory and applications]. (T. Totan, Çev. Ed.). Ankara: Nobel. (Orijinal kitabın yayın tarihi 2012)

Devrim, G. (2010). Profesyonel bir meslek olarak Türkiye’de öğretmenlik. Boğaziçi Üniversitesi Ĕgitim Dergisi, 27 (2), 13-21.

Education, Audiovisual and Culture Executive Agency, (2015). The teaching profession in europe: practices, perceptions, and policies. Luxembourg: Publications Office of the European Union.

Emiroğlu, N. (2000). Sağlık personelinin ve toplumun hemşirelik imajı. Hemşirelik Araştırma Dergisi, 1, 9-18. 
Gönülaçar, Ş. (2016). Türkiye'de ögrretmen imajı ve itibarı üzerine bir inceleme. https://www.academia.edu/20607351/T\%C3\%BCrkiye_de_\%C3\%96\%C4\%9F retmen_\%C4\%B0maj\%C4\%B1_ve_\%C4\%B0tibar\%C4\%B1_\%C3\%9Czerine _Bir_\%C4\%B0nceleme adresinden edinilmiştir.

Hargreaves, A. (2000). Four ages of professionalism and professional learning. Teachers and Teaching: History and Practice, 6(2), 151-182.

Hargreaves, A., and Fullan, M. (2000). Mentoring in the new millennium. Theory into Practice, 39(1), 50-56.

Hargreaves, L., Cunningham, M., Hansen, A., McIntyre, D., Oliver, C., and Pell, T. (2007). The status of teachers and the teaching profession in England: Views from inside and outside the profession (Research Report No. 831A). Retrieved from

https://webarchive.nationalarchives.gov.uk/20130323010453/https://www.educ ation.gov.uk/publications/eOrderingDownload/RR831A.pdf

Secretariat of the Pestalozzi Programme (2014). The Professional image and ethos of teachers. $\quad$ Retrieved from https://www.coe.int/t/dg4/education/pestalozzi/Source/Documentation/T21/Fin RepEn.pdf adresinden erişilmiştir.

Jöreskog, K. G. (2004). On chi-squares for the independence model and fit measures in Lisrel. Retrieved from https://pdfs.semanticscholar.org/c3f8/6332a70bfa6c3ba735b511d58dd9bf9468 8d.pdf?_ga=2.27414073.483348357.1564143443-1128486645.1564143443

Karaman, N. (2008). Öğretmenlerin mesleklerini algllama biçimleri ve gelecekten beklentileri beklentileri (Yayımlanmamış yüksek lisans tezi). Trakya Üniversitesi Sosyal Bilimler Enstitüsü, Edirne.

Karamustafaoğlu, O. ve Özmen, H. (2004). Toplumumuzda ve öğretmen adaylari arasinda öğretmenlik mesleğine verilen değer üzerine bir araştırma. Değerler Ĕ̌itimi Dergisi, 2(6), 35-49.

Karasar, N. (2007). Bilimsel araştırma yöntemi. Ankara: Nobel.

Kıroğlu, K. ve Elma, C. (2009). Eğitim bilimlerine giriş. Ankara: Pegem A.

Kim, E. (2007). The quality and qualifications of the teaching force in The Republic of Korea. In R. M. Ingersoll (Ed.), A comparative study of teacher preparation and qualifications in six nations (pp. 55-70). Retrieved from http://files.eric.ed.gov/fulltext/ED498318.pdf adresinden edinilmiştir.

Kline, R. B. (2011). Principles and practice of structural equation modeling. New York, NY: The Guilford Press. 
Lee, Y. (2010). Views on education and achievement: Finland's story of success and South Korea's story of decline. KEDI Journal of Educational Policy (KJEP) $7(2), 379-401$.

Malaty, G. (2006). What are the reasons behind the success of Finland in PISA? Gazette des Mathématiciens 108(1), 59-66.

Maydeu-Olivares, A., and Garcia Forero, C. (2010). Goodness-of-fit testing. International Encyclopedia of Education, 7, 190-196.

Organisation for Economic Co-operation and Development (2014). The teaching and learning international survey (TALIS) 2013:Main findings from the survey and implications for education and training policies in Europe. Retrieved from . https://ec.europa.eu/assets/eac/education/library/reports/2014/talis_en.pdf

Özdamar, K. (2016). Ĕgitim, sağllk ve davranış bilimlerinde ölçek ve test geliştirme yapısal eşitlik modellemesi. Eskişehir: Nisan.

Özpolat, A. (2002). Sosyolojik açıdan öğretmenlik mesleği ve öğretmenlerin toplumdaki yeri (Yayımlanmamış doktora tezi). İstanbul Üniversitesi Sosyal Bilimler Enstitüsü, İstanbul.

Polat, S. (2011). Üniversite öğrencilerine göre Kocaeli Üniversitesi’nin örgütsel imaj. Eğitim ve Bilim, 36(160), 105-119.

Roberts, L. M. (2003). Changing faces: Professional image construction in diverse organizational settings. Academy of Management Review, 30, 685-711.

Seçer, İ. (2015). Psikolojik test geliştirme ve uyarlama süreci. Ankara: Anı Yayınc1lik.

Semerci, Ç., Semerci N., Eliüşük., A. ve Kartal, E. (2012). Öğretmenlik mesleğinin gündemine ilişkin öğretmen görüşleri (Bartın ili örneği). Bartın Üniversitesi Ĕ̈itim Fakültesi Dergisi, 1(1), 22-40.

Tabachnick, B. G., and Fidell, L. S. (2007). Using multivariate statistics (5th ed.). Boston, Massachusets, MA: Allyn and Bacon.

Tavşancıl, E. (2002). Tutumların ölçülmesi ve SPSS ile veri analizi. Ankara: Nobel.

TEDMEM, (2014). Öğretmen gözüyle öğretmenlik mesleği. Ankara.

Tengelimoğlu, D. ve Öztürk, Y. (2004). İşletmelerde halkla ilişkiler. Ankara: Seçkin Yayıncilik.

Tezbaşaran, A. (2008). Likert tipi ölçek hazırlama kılavuzu. https://www.academia.edu/1288035/Likert_Tipi_Ölçek_Hazırlama_Kılavuzu adresinden edinilmiştir.

Tok, T. N. (1997). Öğretmenlik mesleğinin öğretmenlerin gereksinimlerini karşılama düzeyi. Kuram ve Uygulamada Eğitim Yönetimi, 10(10), 251-267. 
Torun F. (2010). Farklı statülerde çalışan öğretmenlerin öğretmenlik mesleğine bakışları (Isparta örneği) (Yayımlanmamış yüksek lisans tezi). Süleyman Demirel Üniversitesi Sosyal Bilimler Enstitüsü, Isparta.

Türk Dil Kurumu (2018). Güncel Türkçe sözlük. www.tdk.gov.tr adresinden edinilmiştir.

Ünsal, S., ve Bağçeci, B. (2016). Öğretmenlerin mesleki imajlarina ilişkin görüşleri ve mesleki imaja etki eden faktörler. Journal of Human Sciences, 13(3), 39053926. doi:10.14687/jhs.v13i3.3908

Yaman, E., Yaman, H. ve Eskicumalı, A. (2001) Öğretmenlik mesleğinin sosyoekonomik statüsü/bu mesleğin bir bayan mesleği haline dönüşmesi durumu ve eğitim fakültesi üzerine bir araştırma. Sakarya Üniversitesi Ĕ̆itim Fakültesi Dergisi, 2, 53-67.

Yetim, A. ve Göktaş, Z. (2004). Öğretmenin mesleki ve kişisel nitelikleri. Kastamonu Eğitim Dergisi, 12(2), 541-550. 
Ek 1.

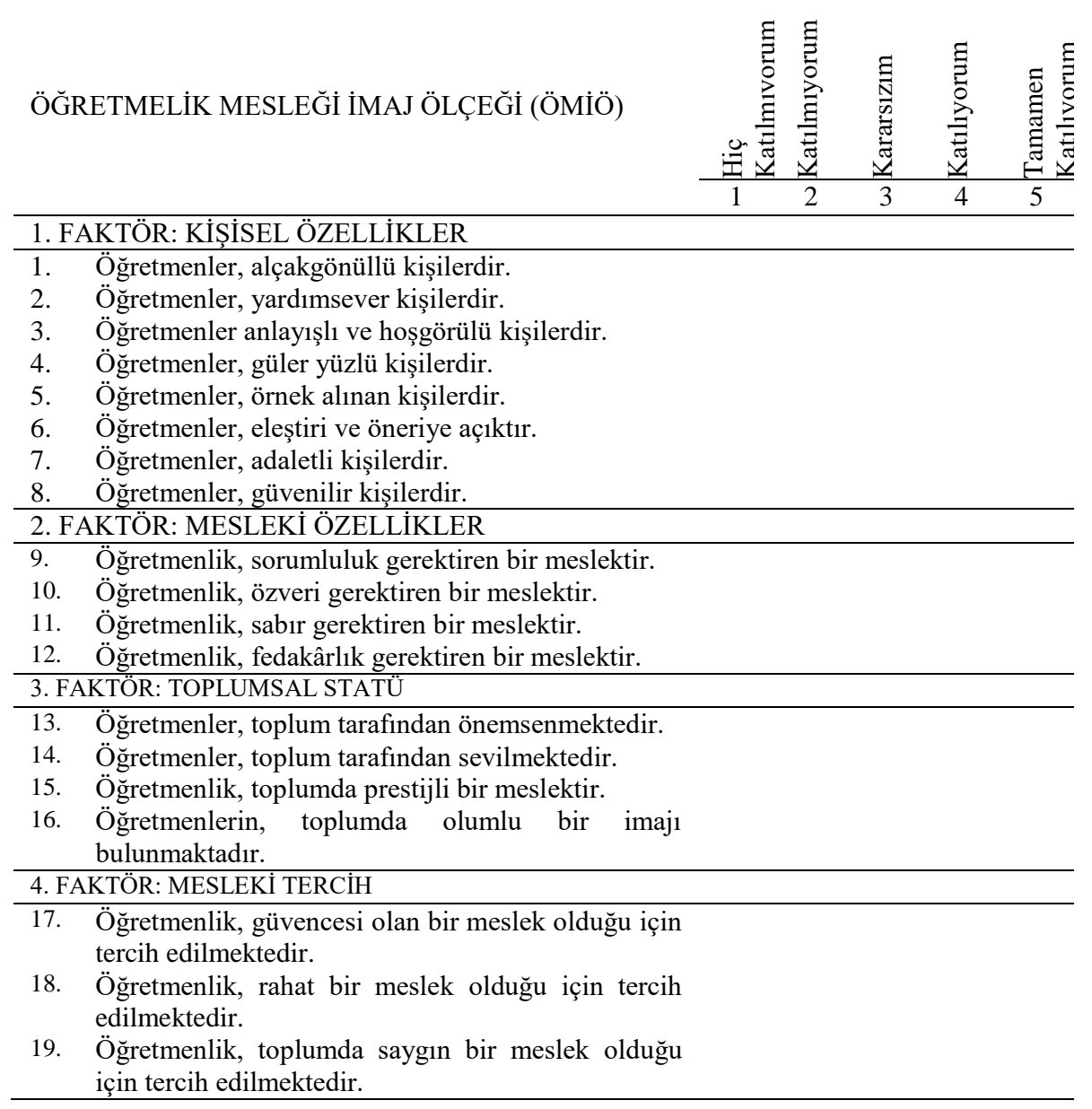




\section{Teacher Image: A Scale Development Study}

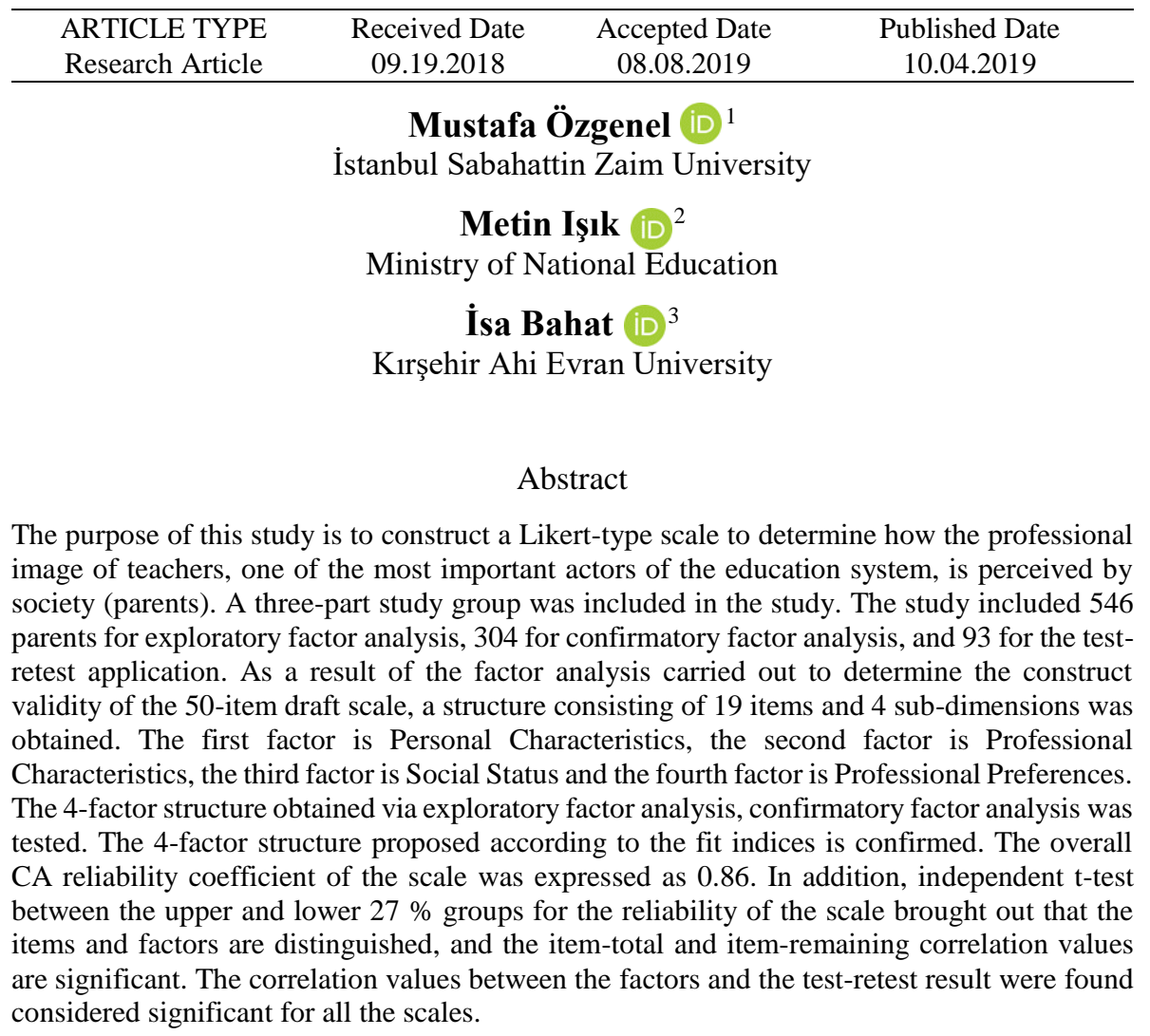

Keywords: Image, teaching profession, professional image.

\footnotetext{
${ }^{1}$ Corresponding Author: Ph.D, Faculty of Education, Department of Primary Education, E-mail: mustafa.ozgenel@izu.edu.tr, https://orcid.org/0000-0002-7276-4865

2Principal, Koç Secondary School, E-mail: metinziya09@hotmail.com, https://orcid.org/0000-0002-08906267

${ }^{3}$ Lecturer, Kaman School of Applied Sciences, Department of Management Information Systems, E-mail: isabahat@ahievran.edu.tr, https://orcid.org/0000-0002-5600-2449
} 


\section{Purpose and Significance}

The objective of This study is to develop a likert-type Scale to reveal how the the profession of teaching and professional images of teachers who are considered to be the major actors of the eaching system are perceived by the society and parents who are able to make close observations about the profession. The scale developed in this respect make great contribution to the studies to be conducted for teachers and profession.

The parents consider the teaching profession as significant, however most of the teachers think that their social status has been degraded and that the importance and value attached to teachers by the state reduced. It is of high importance to improve the qualifications and competencies of teachers so that the perceptions towards teachers and the teaching profession would turn into a positive direction. This study will help to see the place and significance of teaching profession in the public eye and to develop a scale which can be used for studies to be conducted in this sphere. In other words, the first and perhaps the most important way of identifying and shaping the image of the teaching profession is to measure how the parents of the students who represent the society and who receive education are perceived by their parents.

\section{Method}

In this study, Likert-type scale techniques were utilized in order to develop an image scale for the teaching profession. 546, 304 and 93 student parents were reached respectively for factor analysis, confirmatory factor analysis, and test-retest execution. $61.7 \%$ (337) of the parents are female and $38.3 \%$ (209) of the same are male in exploratory factor analysis. Among the parents, $3.3 \%$ (18) are between 20-30 yearsold, $50.5 \%$ (276) are between 31-40 years old, $39.6 \%$ (216) are between 41-50 yearsold and $6.6 \%$ (36) of the same are 51 year old and over; furthermore, $24.2 \%$ (132), $19.8 \%$ (108), $33.0 \%$ (180), $10.1 \%$ (55) and $13.0 \%$ (71) of the parents graduated from primary school, secondary school, high school and the parents hold associate and bahcelors degree respectively. 304 parents in total i.e., 163 women and 141 men, took part in confirmatory factor analysis and 93 parents in total, 50 women and 43 men, took part in test-retest execution.

So as to check out the validity of the scale, literature regarding the image of teaching profession was reviewed, theoretical studies and scales with respect to the issue were reviewed, item pool was created, opinions of teachers and specialists were asked, descriptive analysis, exploratory factor analysis, scale total score and correlation analysis among the factors as well as confirmatory factor analysis were conducted. In the course of developing the Image Scale for Teaching Profession, it was initially determined how the parents identify and perceive the characteristics, i.e., image of the teaching profession which teachers should have. The characteristics of the teaching profession, teacher competences and empirical studies in the literature were reviewed so as to identify and the image of the teaching profession. 
An item pool was created in complicance with theoretical information and respective scales and a draft scale with 67 items was developed. To evaluate the draft scale in terms of form, content, comprehensibility, and grammar, 7 specialists in the field performing of assessment and evaluation and educational administration were provided with a graded form. 17 items, which were not considered applicable by the specialists were removed from the scale.

\section{Results}

The scale consists of 19 items and 4 sub-dimensions. The amount of described variance rate was checked in order to be able to determine the factor number of the scale and it was also ascertined that the scale comprises four factors. The first factor is titled as Personal Characteristics, the second factor as Professional Characteristics, the third factor as Social Status, and the fourth factor as Professional Preference. Reliability coefficients for Personal Characteristics sub-dimension, Professional Characteristics sub-dimension, Social Status sub-dimension, Professional Preference sub-dimension were determined to be $.91, .80, .77$, and .68 respectively and the general reliability coefficient was determined to be .86 . A testretest run was performed to ensure the reliability of the scale regard to the determination of the scale. Following the test-retest run between the factors and total score, correlation coefficients between the factors range between $r=.418$ and $r=.565$. There is no observed significant difference following the t-test regarding dependent groups $(\mathrm{p}>.05)$.

\section{Discussion and Conclusions}

The public opinion of the teachers and the public and the teaching profession can increase the attractiveness of teaching profession. The objective of this study is to develop a Likert-type scale for revealing how professional images of teachers, who are the major actors of the teaching system, are perceived by society. In order to obtain evidences with respect to the validity of the scale, (Çokluk, Şekercioğlu and Büyüköztürk, 2012) Exploratory Factor Analysis (EFA) was made (Baykul, 2015). Before starting the factor analysis, it was determined if KMO and Barlett's test results are in compliance with Exploratory Factor Analysis. Following EFA, the pattern, which was obtained with 19 items and 4 factors. The first factor is titled as Personal Characteristics, the second factor as Professional Characteristics, the third factor as Social Status, and the fourth factor as Professional Preference. In this respect, it could easily be said that the scale creates a tends to create whole and that it has internal consistency. It can be acknowledged that there is a significant relation between the entire scale and its items the which are related to the public opinion of teaching profession. Following the test-retest run, it could be said that there is a positive and significant relation between the total score. Based on these results, it can be stated that the scale is coherent and reliable in terms of determination.

Studies and analysis conducted in this context can be provided as an evidence of the fact that the scale is valid and reliable. Following the validity and reliability 
analysis and studies thereof, the scale was entilled as Image Scale for The Teaching Profession. Final state of the sub-dimension and item distribution of the scale are listed as follows.

- Personal Characteristics: 1, 2, 3, 4, 5, 6, 7, 8

- Professional Characteristics: 9, 10, 11, 12

- Social Status: $13,14,15,16$

- Professional Preference: $17,18,19$

Studies were performed through teachers in order to evaluate the image of the teaching profession, however it was observed that no sufficient studies have been conducted to determine the social perception. In this respect, it is of capital importance to study the social image of the teaching profession. Using the Image Scale for the Teaching Profession developed to be conducted in the empirical studies will contribute not only to the validity but also to reliability of the scale and the literature. 